\title{
Symmetry and Rotation Skills of Prospective Elementary Mathematics Teachers*
}

\author{
Habilidades de Simetría y Rotación de los Futuros Profesores de \\ Matemáticas Elementales
}

\author{
Melih Turgut $^{* *}$ \\ Kürşat Yenilmez $^{* * *}$ \\ Pinar Anapa $^{* * * *}$
}

\begin{abstract}
The aim of this study was to investigate the skills and deficiencies of senior university students enrolled in a mathematics education program with the concepts of symmetry and rotation of geometric figures. The study was conducted with 32 prospective teachers in the Department of Education at a public university located in Western Turkey. This descriptive study was designed with a case study. A structured interview technique was used for data collection. A measurement tool consisting of 12 drawing problems testing symmetry (5 problems) and rotation (7 problems) ability was used in the study. Descriptive statistical methods were used for data analysis. The drawings were analyzed individually, and the students' mistakes and deficiencies were categorized. According to the results of the study, prospective elementary mathematics teachers did not have difficulty in drawing the symmetry of an object or in determining the symmetry axis. However, while they could rotate the figure when a rotation axis was provided, they failed to rotate it in the absence of an axis. In addition, prospective elementary mathematics teachers generally failed to find the center of the given rotated figures. The results of the present study were consistent with results in the literature.
\end{abstract}

Keywords: Symmetry skill, rotation skill, prospective elementary mathematics teacher.

\section{Resumen}

El objetivo de este estudio fue investigar las habilidades y dificultades de los estudiantes de un curso de formación de profesores de matemáticas en relación con los conceptos de simetría y rotación de figuras geométricas. El estudio se llevó a cabo con 32 futuros profesores en un departamento de educación de una universidad pública ubicada en el oeste de Turquía. Éste es un estudio descriptivo que está diseñado con un estudio de caso. Para la recopilación de los datos se aplicó una técnica de entrevista estructurada. En el estudio se utilizó una herramienta de medición consistente de doce problemas de dibujo, cinco sobre la capacidad en la simetría y siete en la de rotación. Para el análisis de datos se emplearon métodos de estadística descriptiva. Los dibujos fueron analizados de forma individual y se clasificaron los errores y las deficiencias de los estudiantes. De acuerdo con los resultados del estudio, los futuros profesores de matemáticas elementales no tuvieron dificultad en dibujar la simetría de un objeto o en hallar el eje de simetría. Sin embargo, mientras que ellos

\footnotetext{
${ }^{*}$ A preliminary and short version of this paper was presented at the $10^{\text {th }}$ Mathematics Symposium on 21-23 September 2011, İstanbul, Turkey.

** PhD in Mathematics Education. Assistant Professor, Faculty of Education, Eskişehir Osmangazi University, Meşelik Campus, Odunpazarı, Eskişehir, 26480, Turkey.E-mail: mturgut@ogu.edu.tr.

*** PhD in Mathematics. Associate Professor, Faculty of Education, Eskişehir Osmangazi University, Meşelik Campus, Odunpazarı, Eskişehir, 26480, Turkey. E-mail: kyenilmez@ogu.edu.tr.

**** PhD in Mathematics. Associate Professor, Faculty of Education, Eskişehir Osmangazi University, Meşelik Campus, Odunpazarı, Eskişehir, 26480, Turkey.E-mail: panapa@ogu.edu.tr.
} 
pudieron rotar la figura cuando se proporcionaba un eje de rotación, fallaron al rotar el objeto cuando no se le dio dicho eje. Además se observó que generalmente se equivocaban al localizar el centro de las figuras rotadas. Los resultados del presente estudio fueron consistentes con los de la literatura.

Palabras clave: Habilidad para la Simetría; habilidad para rotar; futuro profesor de matemáticas elementales.

\section{Introduction}

The possibility of observing symmetry requires that this concept be included in all teaching programs, from primary school teaching to the university level. Aksoy and Bayazit (2010) stated

[...] learning the theoretical knowledge of symmetry is important for students to understand nature, to develop aesthetic emotions, to succeed in other fields of mathematics, and to comprehend certain ideas that are taught within the scope of other disciplines, such as biology and physics (p. 187).

Accordingly, an analysis of the primary school mathematics teaching programs reviewed in this study shows that they have emphasized students' understanding of this concept. For example, in a $1^{\text {st }}$ and $5^{\text {th }}$ grade Mathematics Course, similarity is analyzed as a sub-learning domain in the $1^{\text {st }}$ grade, while symmetry is analyzed as a sub-learning domain in the $2^{\text {nd }}$ grade, an approach that was first implemented in the 2005-2006 academic year (OLKUN, 2006). In addition, according to Yavuzsoy Köse and Özdaş (2008)

$[\ldots]$ the concept of symmetry plays a key role in the comprehension of reflection, rotation, translation, and reflective translation, which are subjects that are included in the transformation geometry sub-learning domain, beginning in the $6^{\text {th }}$ grade elementary education (p. 824).

According to Aksoy and Bayazit (2010), symmetry refers to the act of repositioning a geometric figure or mathematical object in the same or different plane or space by conserving its essence and characteristics under reflection, rotation, and translation movements. They stated that this definition highlights the basic and principle components of the symmetry concept, which requires the following conditions (AKSOY; BAYAZIT, 2010, p. 191): "i) the presence of a geometric or mathematical object, ii) reflection, rotation, and translation movements performed on the object, and iii) a positioned version of the initial object in a new plane/space without an undergoing a change".

The related literature demonstrates that known problems exist with teaching the concepts of symmetry, rotation, and translation, termed geometric transformations, at the elementary and secondary education levels (HOYLES; HEALY, 1997; YAVUZSOY KÖSE; ÖZDAŞ, 2009; PANAOURA et al., 2009). Zavlavsky (1994) observed that the students' difficulties with symmetry are often related to the teachers' misunderstandings of the concept. 
In particular, similar findings in the literature reported that prospective elementary teachers experienced problems related to translation, reflection, rotation, and forming and recognizing transformations (DESMOND, 1997; EDWARD; ZAZKIS, 1993; LAW, 1991; LEIKIN et al., 2000a; LEIKIN et al., 2000b; SON, 2006; YANIK; FLORES, 2009).

Leikin et al. (2000a) investigated the level of knowledge on symmetry and its axis of 14 prospective teachers within the theoretical framework of learning through teaching. Each prospective teacher was asked to review pedagogical and mathematical literature and real world problems for 20-30 minutes to allow the students to make interpretations. Pre-tests and post-tests were conducted to analyze changes in the prospective teachers' knowledge on symmetry, and their presentations were videotaped and analyzed. According to the results of the study, two main types of incorrect responses involving the determination of line symmetry were found: i) identifying an incorrect symmetry axis, and ii) failing to recognize a correct symmetry axis. Furthermore, the researchers observed that only 3 out of the 14 prospective teachers correctly answered $70 \%$ of the questions on the 15 question pre-test. However, 10 out of the 14 prospective teachers correctly answered $70 \%$ of the questions on the post-test, but they were very weak in determining the axis. Son (2006) investigated how pre-service teachers understand reflective symmetry and what types of pedagogical strategies they use to help a student who has a misunderstanding of the subject. A large portion of pre-service teachers had a limited understanding of this concept and had a tendency to rely on its procedural aspects when helping a student understand it correctly, although they recognized a student's misconceptions of the conceptual aspects. Furthermore, Son found that an even larger portion of these pre-service teachers, who showed a sound understanding of reflective symmetry, relied heavily on its procedural aspects.

Yanik and Flores (2009) analyzed the interpretation and knowledge formation process regarding translation transformation for a prospective primary education teacher named Jeff, assessed during a teaching process that also analyzed other geometrical transformations. Jeff's initial perceptions about the subject were observed as the undefined motions of a single object. Jeff conceived transformations as movement and showed no indication of understanding what defined it. The results of the study revealed that his thinking about translations and other rigid transformations produced: i) transformations as undefined motions of a single object, ii) transformations as defined motions of a single object, and iii) transformations as defined motions of all points on the plane. Edward and Zazkis (1993) provided figures to 14 prospective elementary teachers and requested that they rotate those 
figures. The results indicated that their primary images of rotations and reflections featured center points generally located at the visual center of the figures or in a few cases, at a special vertex. Another study on prospective elementary teachers' abilities with geometric transformations was undertaken by Law (1991), who investigated how they learn geometric transformations and how they structure processes of knowledge. The 18 prospective teachers were taking a geometry course at the time of study and were asked to define and provide examples of geometric transformations. The researcher observed that they had difficulties defining these transformations either in a concrete manner or using abstract terms. According to Desmond (1997), they also had difficulties determining the correct transformation and motion attributes required to move an object from one to another and the results of transformations involving multiple combinations of figures. Desmond (1997) observed that out of the 83 prospective elementary teachers studied, only $17 \%$ identified a translation with the correct distance and direction, 24\% recognized a reflection with the correct line of reflection, and $18 \%$ identified a rotation with the correct point, direction, and degrees of rotation on the items.

Previous studies from around the world have shown that prospective elementary teachers generally had limited expertise of symmetry and rotation; they do not have the desired level of knowledge required and produced incorrect drawings. Because a review of the literature did not reveal a similar study in Turkey, the aim of the present study was to analyze these skills in prospective elementary mathematics teachers in Turkey. In addition, highlighting important concepts such as symmetry and rotation will help students develop spatial skills. It was emphasized that the concept of spatial ability was very important for mathematics teaching and for the students' ability to draw explanatory figures in the mathematical thinking process and for their achievement in geometry (TURGUT, 2007). Furthermore, such skills are important for prospective elementary mathematics teachers. The researchers observed that freshman through senior students had difficulty drawing symmetries of given figures when drawing a graph of the inverse relation using a $y=x$ line in general mathematics, abstract mathematics, and analysis courses which are core lectures for prospective elementary mathematics teachers in Turkey. This study was performed in parallel on $4^{\text {th }}$ grade prospective elementary mathematics teachers to determine whether these problems continue in senior grades and in the transition to teaching. 


\section{Methods}

This qualitative study analyzed the symmetry and rotation skills of prospective elementary mathematics teachers. A case study design was used within the scope of a descriptive approach to investigate the problem, which allowed researchers to study one aspect of an analyzed problem deeply. This method is particularly suitable for individual studies, and enabled researchers to examine one aspect of the problem thoroughly (ARSLAN et al., 2011; ÇEPNI, 2007; YIN, 2003).

\subsection{Study group}

The study was conducted with 32 prospective elementary mathematics teachers (22 female, 10 male) who were enrolled as senior university students in the Department of Education at a government university in Western Turkey.

\subsection{Instruments}

A form consisting of 12 drawing problems was used to measure the symmetry and rotation skills of prospective elementary mathematics teachers. Of these 12 drawing problems, 5 involved symmetry, 4 involved rotation, and 3 involved finding the rotation center. In the literature, a scale consisting of 40 differently structured problems on this subject was developed by Dixon (1995). Because Dixon (1995) conducted the study on elementary school students, only 3 out of the 40 questions on rotation and finding the rotation center were directly taken from the scale and other questions included were developed parallel to the examples of Dixon (1995). Variation and peer review (expert analysis) strategies were used to improve the quality of the qualitative study as reported by Yildirım (2010), focused on increasing the validity and reliability of the scale. For data variation, a pilot study was conducted by administering prepared questions to a teacher who was enrolled in an elementary mathematics teaching graduate program. The obtained findings were analyzed by the researchers and an expert, who is specialized in mathematics education, as part of the peer review strategy. The problems were well suited for analyzing symmetry and rotation skills and the mistakes and deficiencies of prospective elementary mathematics teachers. The final version of the drawing problems presented to the study group can be found in the Appendix. 
The first five questions tested the symmetry and axis skills of the prospective elementary mathematics teachers. Questions 6-9 tested rotation skills and questions 10-12 tested their skills with finding the rotation center of a given rotated figure. Considering the difficulty of the problems on rotation and finding the rotation center, as well as the completion time of the post-graduate student in the pilot study, the students were allotted 15 minutes to answer the questions and the data was collected by the researchers.

\subsection{Data analysis}

A content analysis method was used for data analysis. Coding, finding themes, and the organization of data according to code and theme stages reported by Yıldırım and Şimşek (2005) were used as a basis. The students' answers to drawing problems were analyzed by each researcher for each question. First, the drawing papers of each student were numbered from 1 to 32. Errors, deficiencies, and different strategies in the answers were categorized. In addition, all drawings were categorized by an expert, who was specialized in this area of education for peer review. The main categories obtained were constantly compared with the other, and common or similar categories in the analysis report of each researcher were highlighted.

\section{Findings}

The findings based on the analysis of the data obtained from drawing problems aimed at analyzing the symmetry and rotation skills of prospective elementary mathematics teachers are presented below in three sections.

\subsection{Findings on symmetry and symmetry axis}

The students' answers to the symmetry and symmetry axis problems and findings on their drawings are presented in this section and summarized in the Table 1. 
Table 1 - General Information about the Responses on Symmetry and Symmetry Axis

\begin{tabular}{ccccccc}
\hline Question Number & Correct Answer & $\%$ & Wrong Answer & $\%$ & Blank & $\%$ \\
\hline 1 & 20 & 62.5 & 12 & 37.5 & - & 0 \\
2 & 18 & 56.2 & 14 & 43.8 & - & 0 \\
3 & 29 & 90.6 & 3 & 9.4 & - & 0 \\
4 & 29 & 90.6 & 3 & 9.4 & - & 0 \\
5 & 29 & 90.6 & 3 & 9.4 & - & 0 \\
\hline
\end{tabular}

Source: Developed by authors

Although all the 32 prospective elementary mathematics teachers were expected to correctly answer the first five questions, $100 \%$ success was not observed. The first and second questions on the problem form involved drawing the symmetry of a given figure according to its axis, whereas the remaining questions asked whether two given figures were symmetric and required the determination of its symmetry axis. Based on the percentage of students who incorrectly answered these easy questions, we determined that the prospective elementary mathematics teachers in the work had weak symmetry skills. In addition, the errors and deficiencies in the students' drawings were individually analyzed by the researchers and categorized under the themes outlined in Table 2.

Table 2 - Themes Determined for the Drawings about Symmetry and Symmetry Axis

\begin{tabular}{lllll}
\hline \multicolumn{1}{c}{ Theme } & Yes & $\%$ & No & $\%$ \\
\hline Attention to the distance of the symmetry axis in drawings & 22 & 68.8 & 10 & 31.2 \\
Attention to the curvilinear property of the figure whose & 18 & 56.3 & 14 & 43.7 \\
symmetry was drawn & & & & \\
\hline
\end{tabular}

\section{Source: Developed by authors}

In general, the students did not have difficulty drawing the symmetry of the figures; however, they did not pay attention to the figure itself or to the line (axis) when drawing it. Furthermore, certain interesting findings were obtained in the analysis of the drawings on symmetry and its axis. For example, students 2, 11, 13, 25, and 32 could not draw the symmetry of the given flag figure according to the line, as shown in the sample drawings in Figure 1.

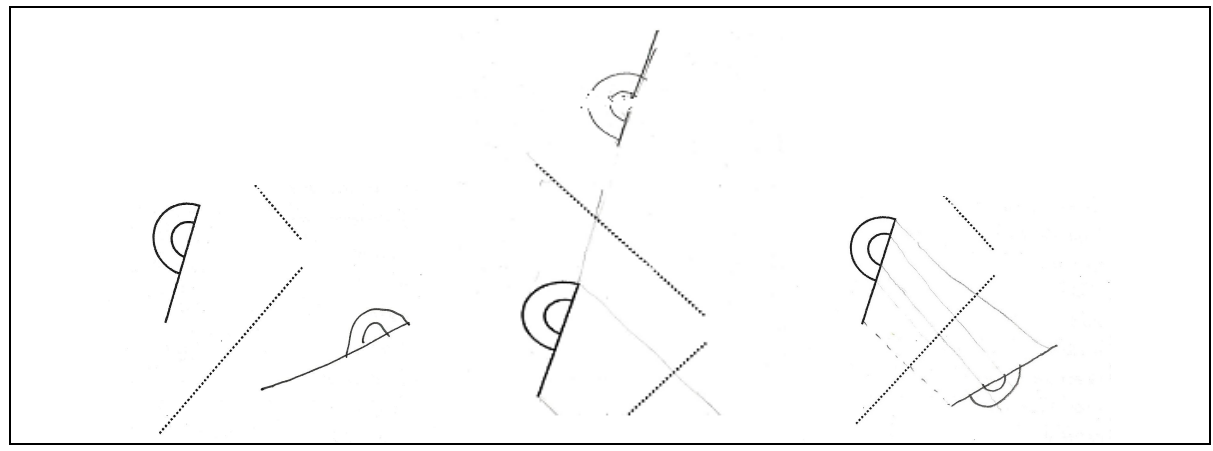

Figure 1 - Sample drawings from students 2, 11, and 25, respectively Source: Data of research 
Student number 13 made the same error as student number 11 (shown in the middle of Figure 1). These students did not use the symmetry axis and had serious deficiencies in their proficiency on this concept. Similarly, it was interesting that student 25 tried to draw the symmetry of the flag but did not consider the figure itself (shown on the right side of Figure 1). An analysis of the obtained data showed that students $2,7,10$, and 32 drew the symmetry axis for two figures that were not symmetrical (example drawings are shown Figure 2).

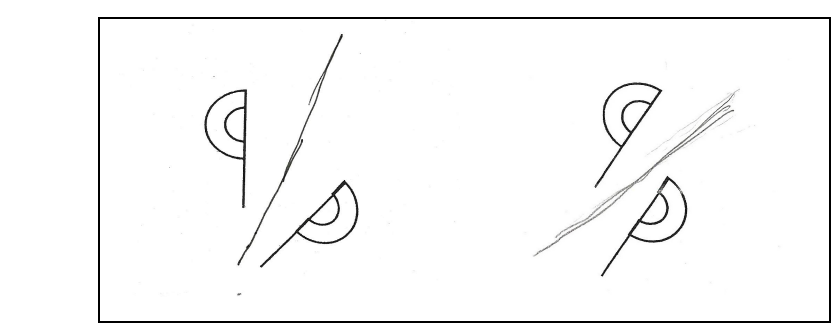

Figure 2 - Sample drawings from students 2 and 7, respectively Source: Data of research

Student 10 made the same mistake as student 2 (shown on the left side of Figure 2). These two students did not know that the points of two symmetric objects on the figure should also be at an equal distance. Student 32 made the same mistake as student 7 (shown on the right side of Figure 2). They may have formed this incorrect symmetry axis due to insufficient spatial visualization skills. These drawings highlighted their low skill levels in finding the symmetry and its axis in general.

Examples of the second theme, paying attention to the curvilinear property of the figure which symmetry was drawn, are presented below in Figure 3. Fourteen out of the 32 prospective teachers analyzed (43.7\%) did not mind the curvilinear form of the figure when drawing symmetry. For example, the incorrect drawing made by student 3 is shown in the left side of Figure 3.

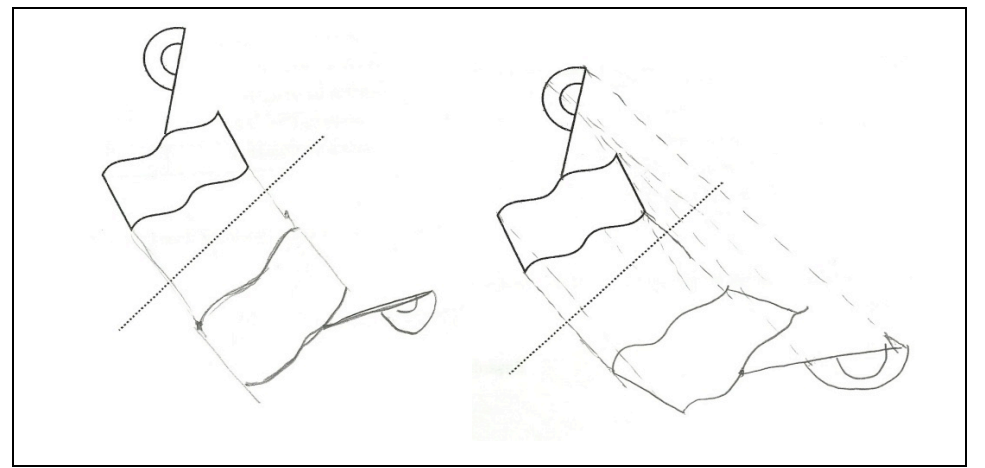

Figure 3 - Sample drawings from students 3 and 8, respectively Source: Data of research

The errors of the other students were also similar to student 3 , and these prospective elementary mathematics teachers did not consider attention to the symmetry axis while 
drawing curvilinear figures. These drawings were also categorized in the first theme, paying attention to the distance to the symmetry axis. While student 3 followed the correct strategy at the beginning with the line segments he/she drew, the student failed to produce the correct drawing of the general figure. Another error associated with the second theme was observed with student 8 (shown on the right side of Figure 3). Student 8 used additional drawings to pay attention to the symmetry axis; however, he/she did not observe the curvilinear figure. These findings also support the conclusion that prospective elementary mathematics teachers had weak symmetry skills.

\subsection{Findings on rotation}

The results from the students' answers to rotation problems and drawings are presented in this section and below in Table 3.

Table 3 - General Information on the Responses to Rotation Questions

\begin{tabular}{lllllll}
\hline Question No & Correct Answer & $\%$ & Wrong Answer & $\%$ & Blank & $\%$ \\
\hline 6 & 15 & 46.9 & 16 & 50 & 1 & 3.1 \\
7 & 23 & 71.9 & 9 & 28.1 & - & 0 \\
8 & 6 & 18.8 & 23 & 71.9 & 3 & 9.4 \\
9 & 15 & 46.9 & 14 & 43.8 & 3 & 9.4 \\
\hline
\end{tabular}

Source: Developed by authors

Prospective elementary mathematics teachers also had a very low level of rotation skills. In general, the students did well with question 7 and had difficulty with question 8 . The themes observed as the cause of major difficulty with question 8 and moderate difficulty with questions 6 and 9 are shown in Table 4 below.

Table 4 - Themes Determined About the Findings of Questions about Rotation

\begin{tabular}{lllll}
\hline Theme & Yes & $\%$ & No & $\%$ \\
\hline Paying attention to the rotation angle & 16 & 50 & 16 & 50 \\
Paying attention to the rotation center and distance & 12 & 37.5 & 20 & 62.5 \\
Paying attention to the given figure & 10 & 31.2 & 22 & 68.8 \\
\hline
\end{tabular}

Source: Developed by authors

As indicated in Table 4, there were significant deficiencies and mistakes in the rotation skills of prospective elementary mathematics teachers. In general, the students did not pay attention to the rotation angle and mark when performing a rotation operation. In addition, they did not think about the rotation operation by taking into account the rotation center, distance, and given figure. Some examples of the general errors made are presented below in Figure 4. 


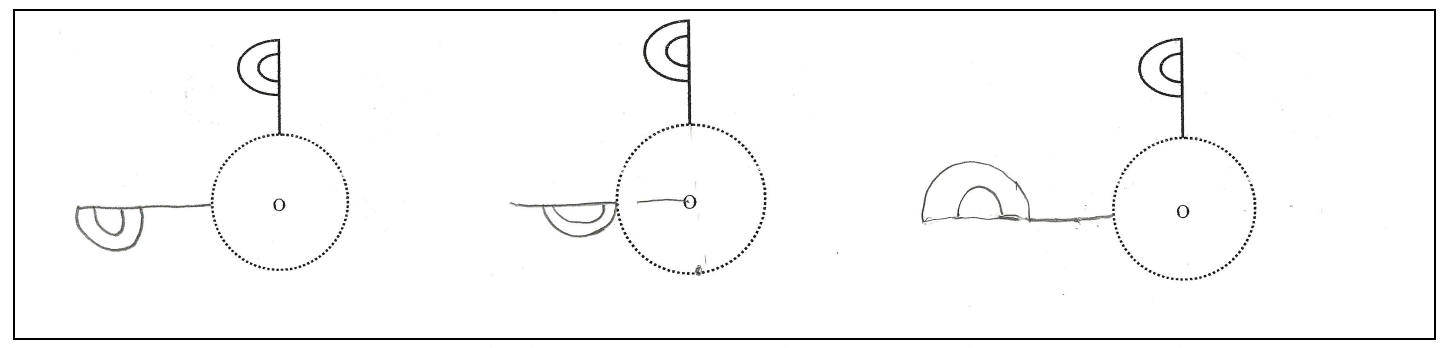

Figure 4 - Sample drawings from students 1, 8, and 10, respectively

Source: Data of research

Paying attention to the rotation angle was the first theme identified in the content analysis, and half of the sample group was included in this category. As shown in student 1's drawing on the left side of Figure 4, they did not pay attention to the scale of the angle, and many people make the same error. Student number 8 made a similar, interesting mistake (shown on the middle of Figure 4) and modified the figure during rotation. However, in question 6 , the students were only asked to rotate the figure -90 degrees. The drawing on the right side of Figure 4 made by student 10 is an example of the first and third themes, regarding the rotation angle and the given figure, respectively. An analysis of the drawing made by student 10 revealed that he/she initially produced the correct drawing, using the symmetric of the figure while rotating it. However, student 10 did not pay attention to the figure. Incorrect drawings for questions 7, 8, and 9 on rotation are shown in Figures 5-6 below. In general, the students drew question 7 correctly and considered the scale of the angle. Conversely, incorrect drawings were related to the third theme and were drawn by students who did not watch the figure during rotation as shown in Figure 5 for student 3.

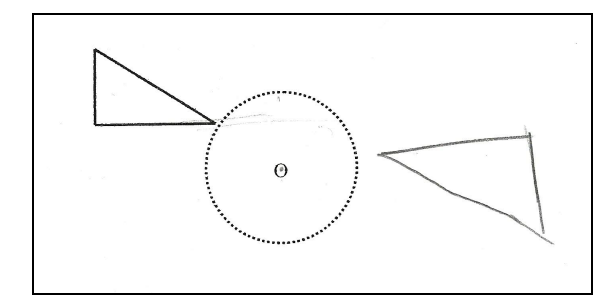

Figure 5 - Sample drawing from student 3 Source: Data of research

Question 9 was one of the most incorrectly answered questions administered to the students. The examples presented in Figure 6 show the second theme regarding the rotation center and distance. The first student's mistake was taking the rotation center as the edge of the given figure. The drawing made by student 3 (shown on the left side of Figure 6) illustrates the most common mistake made by 11 students $(35 \%)$. They were asked to rotate the figure around a center $(\mathrm{O})$ in the positive direction and the majority of them made the same mistake. Although rotations in the positive direction were provided, some students made 
rotations in the negative direction. Because the rotation challenged them, they immediately tried to rotate the figure on the edge point. Some of the people reached the solution by drawing a circle around the center, and this strategy was helpful. Sample drawings showing other common mistakes are presented below in Figure 6.

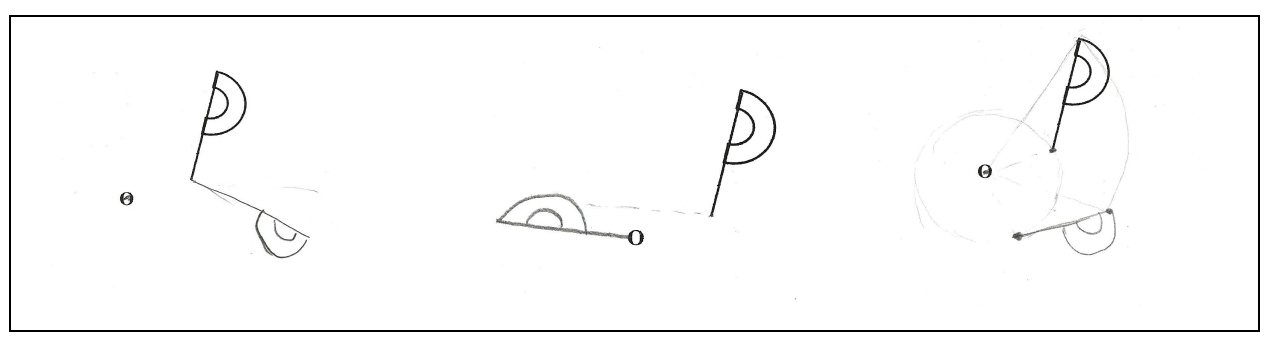

Figure 6 - Sample drawings from students 3, 4 and 17, respectively

Source: Data of research

The majority (7) of the students made the same error (shown in the middle of Figure 6). Although they were asked to make the rotation around the center, they were not attentive to the rotation center or to the distance between the figure and its rotation center. Furthermore, they generally observed the angle in this drawing problem, although some of them did not, such as student 17 (shown on the right side of Figure 6). A total of 5 students (16\%) rotated the figure in the negative direction. Out of these people, 4 made the rotation in the negative direction without drawing an axis. Student 17 made the mistake of drawing the figure in the opposite direction, although he/she made an axis to the rotation center. In general, analysis of the drawings related to the rotation revealed that the students were able to rotate the figure; however, they did not consider the rotation center, the distance to it, and the mark of the angle. Some of them displayed a combination of these mistakes.

\subsection{Findings about rotation center}

In this section, the students' drawings on rotation operations were analyzed and the findings obtained from 3 questions are summarized in Table 5 below.

Table 5 - General Information on the Finding of Rotation Center

\begin{tabular}{lllllll}
\hline Question No & Correct Answer & $\%$ & Incorrect Answer & $\%$ & Blank & $\%$ \\
\hline 10 & 30 & 93.75 & 0 & 0 & 2 & 6.25 \\
11 & 8 & 25 & 18 & 56.25 & 6 & 18.75 \\
12 & 1 & 3 & 10 & 32 & 21 & 65 \\
\hline \multicolumn{7}{r}{ Source: Developed by authors }
\end{tabular}

As shown in Table 5, the majority of students drew the question 10 correctly. The ratio of the correct answers was: incorrect drawing decreased in question 11, and question 12 was 
only drawn correctly by 1 student. Analysis of the students' drawings revealed that mistakes were concentrated on only one theme presented in Table 6 below.

Table 6 - Theme Determined about the Finding of Rotation Center

\begin{tabular}{lcccccc}
\hline Theme & Yes & $\%$ & No & $\%$ & Unanswered & $\%$ \\
\hline $\begin{array}{l}\text { Understanding that the rotated object is at } \\
\text { an equal distance to the center }\end{array}$ & 39 & 40.6 & 28 & 29.1 & 29 & 30.3 \\
\hline
\end{tabular}

Source: Developed by authors

An analysis of the answered frequencies of the last three questions on rotation center showed that students found the center correctly in 39 of the 96 answers, incorrectly in 28 of the answers, and left 29 of them unanswered. They had very weak skills for finding the rotation center of a given figure. Their drawings were analyzed and themes were produced to understand the difficulty with this concept. All of the students correctly answered question 10, but made serious mistakes in question 11. Common errors observed in question 11 are presented in Figure 7.

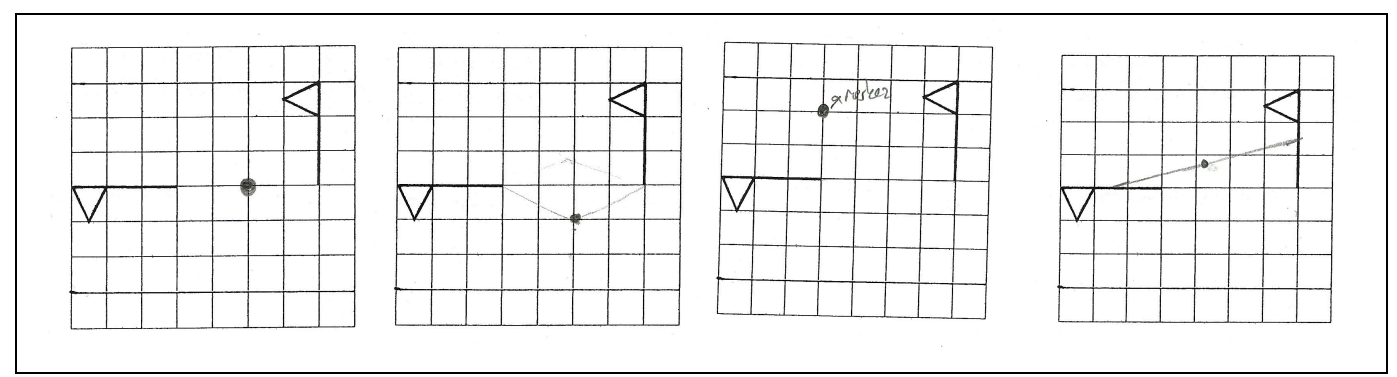

Figure 7 - Sample drawings from students 18, 20, 9 and 6, respectively Source: Data of research

The mistake illustrated by student 18 in Figure 7 was also made by 14 other students $(45 \%)$ and highlighted a problem with mental rotation. Similarly, some prospective teachers who found the same point tried to find the center by drawing a circle with a 2 unit diameter, but found the center incorrectly. In addition, the students made some interesting errors. For example, two people drew the point as shown in the drawing by student 20 (shown in the second drawing in Figure 7). Two of them marked the same point and determined an incorrect location as the center, and the strategy used by these students could not be properly understood. In addition, student 9 had deficiencies in her/his interpretation of the concept of rotation and did not know that the distance should be equal to the center (shown in the third drawing in Figure 7). Similarly, student 6 tried to use the approach of equal distance but did not find the correct answer (shown in the fourth drawing of Figure 7). Student 6 could not visualize the rotation of the flag in his/her mind and did not regard the distance from the object to the center. Additionally, the drawings for the last question were analyzed, where 
only one correct answer was given. The error made by 4 students $(13 \%)$ is presented on the left side of Figure 8, represented by student 14.

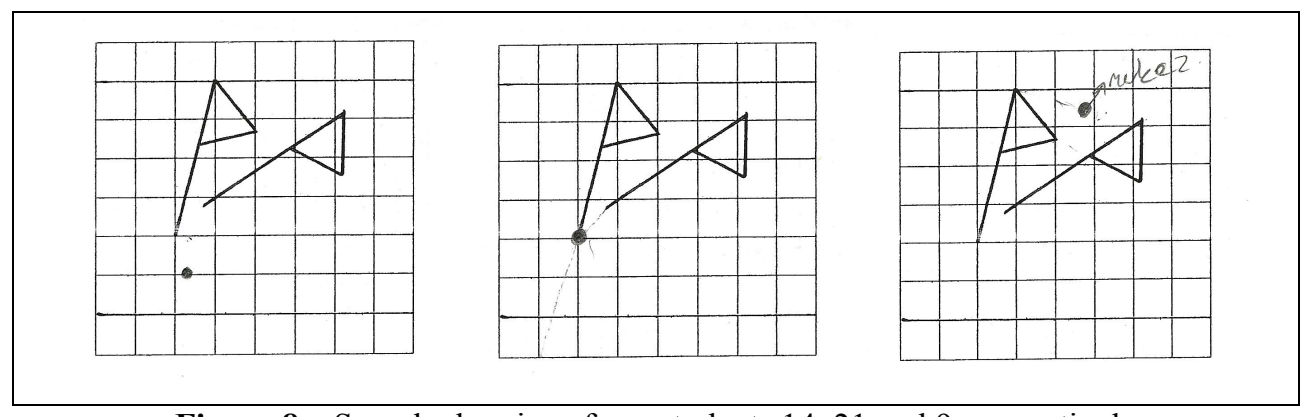

Figure 8 - Sample drawings from students 14, 21 and 9, respectively Source: Data of research

These people had weak rotation skills and did not consider the distance between the point they determined as the rotation center and the object and did not check their drawings. One student did not lengthen the edges of the flag. Two of them $(6 \%)$ marked the point as shown in student 21's drawing (shown in the middle of Figure 8) and this strategy could not be understood. Finally, a drawing made by student 9 (shown on the right side of Figure 8) shows another error that was observed. For the students who found the rotation center as indicated in this drawing, the researchers concluded that they failed to perceive the rotation of the flags and the strategy used by student number 9 could not be understood. It is clearly seen from the figure that the first status of the flag was indicated on the left, while the second status was indicated on the right.

\section{Results and discussion}

The aim of this study was to analyze the symmetry and rotation skills of prospective elementary mathematics teachers and the following conclusions were drawn.

Prospective elementary mathematics teachers did not have much difficulty in drawing the symmetry of an object according to the given axis; however, they experienced difficulty in finding the symmetry axis and in determining whether two given objects were symmetric to one another. This type of error was also observed by Leikin et al. (2000a) and Zavlavsky (1994). This work also revealed that the mistakes generally stemmed from a lack of attention to the symmetry line and the given figure. These results are consistent with the findings of Desmond (1997), Leikin et al. (2000a) and Son (2006). The students could not interpret symmetry, transformation and linear algebra knowledge, especially linear transformations, could not be conceptualized by many of them. Zembat (2007) described this concept and 
emphasized the importance of the know-how of the mathematical analysis of reflective transformation (transformation that turns the points on the line again into line points and maintains distance, isomorphism, etc.) by the teachers.

Prospective elementary mathematics teachers had poor rotation skills. In general, student errors and deficiencies with rotation stemmed from not regarding the rotation angle, rotation center, distance, and the given figure. Furthermore, the students generally failed to determine the center in a rotation. The majority of the mistakes occurred because the students did not observe the equal distance to the rotation center while rotating the object. In other cases, some students (for example, students 6,9,14, and 21) could not analyze the given figure. These results revealed that prospective elementary mathematics teachers were deficient in their knowledge about the concepts of angle and direction. The results are consistent with the findings of Law (1991) and Edward and Zazkis (1993). In addition, they could rotate the figure when the axis was provided, although they were not always correct. However, when the axis was not given, they rotated the figure by taking the edge point of the figure as the rotation point. Although the students were given equal squares to draw more easily, they could not find the rotation centers, which we believe stems from the students' poor visualization and rotation in their minds.

The results obtained from the drawings of prospective elementary mathematics teachers revealed that the spatial abilities of the students should be a focus. Some of them could not draw the symmetry of the figure according to the symmetry line. We believe that deficiencies in these concepts, which are taught in primary education, stem from poor spatial visualization and mental rotation. Recent studies have shown that the spatial abilities of elementary mathematics teachers and prospective teachers were lower than expected and knowledge deficiencies are already known (CANTÜRK-GÜNHAN et al., 2009; TURGUT et al., 2009; TURGUT, 2010), which may be investigated in further research.

In the study, the 13 prospective teachers (40\%) who correctly answered all of the questions on drawing a symmetry axis were among the 21 prospective teachers $(65 \%)$ who correctly answered all of the questions on finding the axis. In addition, 3 prospective teachers $(9 \%)$ correctly answered all 4 questions on rotation, but none of the students correctly answered the questions on the rotation center. However, 4 prospective teachers $(12 \%)$ correctly answered 2 out of the 3 questions on the rotation center. These findings are consistent with the findings of Desmond (1997). We plan to focus on these findings in more depth in further research. 


\section{Recommendations}

Analysis of the students' drawings showed that the concept of symmetry was not adequately understood and evoked the question of whether it is visualized differently in the minds of the students. We were interested in the reasons for the differences in the drawings and case studies could be conducted for further analyses of these differences.

Graduate programs of primary education mathematics teaching do not contain a course for the structuring of these skills. By including a class such as Computer Assisted Mathematics Teaching that presents concepts such as symmetry and rotation in the graduate programs of some universities, contributions can be made towards eliminating the knowledge deficiencies of prospective teachers in these subjects, improving their related skills. According to the latest findings in the literature, students can solidify advanced skills such as geometrical reasoning, geometric proof, and geometric locus with mathematical programs such as Sketchpad, Cabri, or GeoGebra (BAKI, 2005; BAKI et al., 2011; GUVEN; KARATAŞ, 2009; İPEK; AKKUŞ-ISPIR, 2011). Perhaps the deficiencies of prospective elementary mathematics teachers are caused by their knowledge deficiencies at their primary education level. For example, Yavuzsoy Köse and Özdaş (2009) investigated how primary education grade 5 students determined symmetry planes in geometric figures using the Cabri software. They found that the students focused on the equality and reflection of the parts of the symmetry plane formed on the figure, on the congruity of the parts when the figure is visually folded along the line, and on the equality of the side lengths/angle measurements of given figures. In recent years, it was observed that symmetry, rotation, and translation skills of primary education students improved with the use of computer software (FAYDACI; ZEMBAT, 2012; HEALY, 2004; HOLLEBRANDS, 2003; HOYLES; HEALY, 1997). These types of activities can be emphasized starting at the primary education level and prototypes of the same properties can be developed for adults. The conceptualization of these skills can improve the student's ability to handle an object as a whole, to manipulate that object and improve their spatial skills. Skills like symmetry, rotation, and spatial ability, which require visualization, integration, and rotation skills, can be improved using the appropriate media, materials, and technologies (KURTULUŞ, 2011; KURTULUŞ; UYGAN, 2010; TURGUT, 2010; YOLCU; KURTULUŞ, 2010).

In some of the questions used in the study, the students were asked to rotate the given figure in the negative direction, but made the mistake of rotating the figure in a positive direction. These problems were observed in questions 6,7 , and 8 , and an understanding of 
why they did this could not be understood. Analysis concentrating on this confusion can be conducted to eliminate this knowledge deficit.

The elective course Transformation Geometry, which addresses basic geometrical transformations, can be taught to prospective primary education mathematics teachers. Symmetry, similarity, and drawings of certain special transformations can be specifically visualized in this class. Isometric paper drawing activities can also be utilized to improve the spatial abilities of prospective teachers who will educate the engineers and architects of the future.

\section{Acknowledgement}

The authors would like to thank the referees and editors of BOLEMA for their useful suggestions that have substantially improved the presentation of the paper. The first author also would like to thank Tübitak-Bideb (Bayg) (The Scientific and Technological Research Council of Turkey) for their financial supports during his MSc and PhD studies.

\section{References}

AKSOY, Y.; BAYAZİT, İ. Simetri kavramının öğrenim ve öğretiminde karşılaşılan zorlukların analitik bir yaklaşımla incelenmesi. In: ÖZMANTAR, M. F; BİNGÖLBALİ, E. (Ed.). İlköğretimde matematiksel kavram yanılgıları ve çözüm önerileri. Ankara: PegemA Yayıncılık, 2010. p. 187-215.

ARSLAN, S. ARSLAN, S.; KUTLUCA, T.; ÖZPINAR, İ. Investigating mathematics teacher candidates' opinions about using information \& communication technologies. Cypriot Journal of Educational Sciences, Kyrenia, Cyprus, v. 6, n. 2, p. 75-82. June 2011.

BAKI, A. Archimedes with Cabri: Visualization and experimental verification of mathematical idea. International Journal of Computers for Mathematical Learning, The Netherlands, v. 10, n. 3, p. 259-270. Dec. 2005.

BAKI, A.; KOSA, T.; GUVEN, B. A comparative study of the effects of using dynamic geometry software and physical manipulatives on the spatial visualisation skills of pre-service mathematics teachers. British Journal of Educational Technology, Malden, MA, USA, v. 42, n. 2, p. 291-310. Mar. 2011.

CANTÜRK-GÜNHAN, B.; TURGUT, M.; YILMAZ, S. Spatial ability of a mathematics teacher: the case of Oya. IBSU Scientific Journal, Georgia, v. 3, n. 1, p. 151-158. June 2009.

ÇEPNI, S. Araştırma ve proje çalışmalarına giriş. Trabzon, Turkish: Celepler Matbacılık, 2007.

DIXON, J. K. English language proficiency and spatial visualization in middle school students' construction of the concepts of reflection and rotation using the Geometer's Sketchpad. 1995. 180p. Dissertation (Doctor of Philosophy) - The Graduate School of the University of Florida, Florida, 1995. 
DESMOND, N. S. The geometric content knowledge of prospective elementary teachers, Dissertation. 1997. 233 f. Dissertation (Doctor of Philosophy) - The Faculty of the Graduate School of University of Minnesota, Minneapolis, 1997.

EDWARDS, L.; ZAZKIS, R. Transformation geometry: naive ideas and formal embodiments. Journal of Computers in Mathematics and Science Teaching, Chesapeake, VA, USA, v. 12, n. 2, p. 121-145. June 1993.

FAYDACI, S.; ZEMBAT, İ. Ö. Teaching of translations through use of vectors in Wingeom-tr environment. Elementary Education Online, Ankara, Turkey, v. 11, n. 1, p. 173-194, Jan. 2012.

GUVEN, B.; KARATAŞ, İ. The effect of dynamic geometry software (cabri) on pre-service elementary mathematics teachers' achievement about locus problems. Ankara University, Journal of Faculty of Educational Sciences, Ankara, Turkey, v. 42, n. 1, p. 1-31. Jan. 2009.

HEALY, L. The role of tool and teacher mediations in the construction of meanings for reflection. In: Conference of the International Group for the Psychology of Mathematics Education, $28^{\text {th }}, 2004$, Bergen. Proceedings of the $\mathbf{2 8}^{\text {th }}$ International Conference for the Psychology of Mathematics Education. Bergen: Bergen University College, 2004, v. 3, p. 33-40.

HOLLEBRANDS, K.F. High school students' understandings of geometric transformations in the context of a technological environment. The Journal of Mathematical Behavior, Norwood, NJ, USA, v. 22, n. 1, p. 55-72. Mar. 2003.

HOYLES, C.; HEALY, L. Unfolding meanings for reflective symmetry. International Journal of Computers for Mathematical Learning, The Netherlands, v. 2, n. 1, p. 27-59. Sept. 1997.

IPEK, S.; AKKUŞ-İSPIR, O. Preservice elementary mathematics teachers' geometric and algebraic proof process with dynamic geometry software. Turkish Journal of Computer and Mathematics Education, Trabzon, Turkey, v. 2, n. 1, p. 20-34. Jan. 2011.

KURTULUŞ, A. Effect of computer-aided perspective drawings on spatial orientation and perspective drawing achievement. TOJET: The Turkish Online Journal of Educational Technology, Sakarya, Turkey, v. 10, n. 4, p. 138-147. Oct. 2011.

KURTULUŞ, A.; UYGAN, C. The effects of google sketchup based geometry activities and projects on spatial visualization ability of student mathematics teachers. Procedia Social and Behavioral Sciences, Maryland Heights, MO, USA, v. 9, n. 1, p. 384-389. Oct. 2010.

LAW, C. K. A genetic decomposition of geometric transformations. 1991. 147 f. Dissertation (Doctor of Philosophy) - The Graduate School of Purdue University, West Lafayette, 1991.

LEIKIN, R.; BERMAN, A.; ZASLAVSKY, O. Learning through teaching: the case of symmetry, Mathematics Education Research Journal, The Netherlands, v. 12, n. 1, p. 18-36. Apr. 2000a.

LEIKIN, R.; BERMAN, A.; ZASLAVSKY, O. Applications of symmetry to problem solving, International Journal of Mathematical Education in Science and Technology, London, GB, v. 31, n. 6, p. 799-809. November-December. 2000b.

OLKUN, S. Yeni öğretim programlarını inceleme ve değerlendirme raporu: Matematik öğretim programı inceleme raporu. Elementary Education Online, Ankara, Turkey, v. 5, n. 1, p. 96-111. Jan. 2006. 
PANAOURA, A.; ELIA, I.; STAMBOULIDES, N.; SPYROU, P. Students' structure for the understanding of the axis of reflective symmetry in mathematics. Acta Didactica Universitatis Comenianae, Bratislava, Slovakia, v. 9, n. 1, p. 41-62. Dec. 2009.

SON, J. W. Investigating preservice teachers' understanding and strategies on a student's errors of reflective symmetry. Conference of the International Group for the Psychology of Mathematics Education, $30^{\text {th }}, 2006$, Prague. Proceedings of the $\mathbf{3 0}^{\text {th }}$ Conference of the International Group for the Psychology of Mathematics Education. Prague: Charles University, Faculty of Education, 2006, v. 5 , p. $145-152$.

TURGUT, M. Investigation of 6, 7 and 8. grade students' spatial ability (Turkish). 2007. $165 \mathrm{f}$. Dissertation (Master of Science in Mathematics Education) - Institute of Educational Sciences, Dokuz Eylül University, Izmir, 2007.

TURGUT, M. The effect of technology assisted linear algebra instruction on pre-service primary mathematics teachers' spatial ability (Turkish). 2010. 262 f. Dissertation (Doctorate in Mathematics Education) - Institute of Educational Sciences, Dokuz Eylül University, Izmir, 2010.

TURGUT, M.; CANTÜRK-GÜNHAN, B.; YILMAZ, S. An investigation of knowledge level of spatial ability (Turkish). E-Journal of New World Sciences Academy. Elazığ, Turkey, v. 4, n. 2, p. 317-326. Apr. 2009.

YANIK, H. B.; FLORES, A. Understanding rigid transformations: jeff's learning path for translation. The Journal of Mathematical Behavior, Norwood, NJ, USA, v. 28, n. 1, p. 41-57. Mar. 2009.

YAVUZSOY KÖSE, N.; ÖZDAŞ, A. Student experiences regarding research of symmetry lines in geometry shapes by the aid of cabri geometry software. In: INTERNATIONAL EDUCATIONAL TECHNOLOGY CONFERENCE, $8^{\text {th }}, 2008$, Eskişehir. Proocedings of $\mathbf{8}^{\text {th }}$ International Educational Technology Conference. Ankara: Nobel Yayın, 2008, p. 823-828.

YAVUZSOY KÖSE, N.; ÖZDAŞ, A. How do the fifth grade primary school students determine the line of symmetry in various geometrical shapes using Cabri Geometry software, Elementary Education Online, Ankara, Turkey, v. 8, n. 1, p. 159-175, Jan. 2009.

YIN, R. K. Case study research design and methods. 3. ed. New Delhi: London, 2003.

YILDIRIM, K. Raising the quality in qualitative research, Elementary Education Online, Ankara, Turkey, v. 9, n. 1, p. 79-92, Jan. 2010.

YILDIRIM, A.; ŞIMŞEK, H. Sosyal bilimlerde nitel araştırma yöntemleri. Ankara: Seçkin Yayınc1lik, 2005.

YOLCU, B.; KURTULUŞ, A. A study on developing sixth-grade students' spatial visualization ability, Elementary Education Online, Ankara, Turkey, v. 9, n. 1, p. 256-274, Jan. 2010.

ZAVLAVSKY, O. Tracing students' misconceptions back to their teacher: a case of symmetry. Pythagoras, Tygervalley, South Africa, v. 33, n. 1, p. 10-17, June 1994.

ZEMBAT, İ. Ö. The main tenets of direct instruction and constructivism: the case of translations, GÜ Gazi Eğitim Fakültesi Dergisi, Ankara, Turkey, v. 27, n. 1, p. 195-213, Jan. 2007. 


\section{APPENDIX}

Symmetry and Rotation Scale-Your symmetry and rotation skills will be evaluated in this scale.

Please draw the requested figures.

Draw symmetries of the figures below according to the given lines.

1.

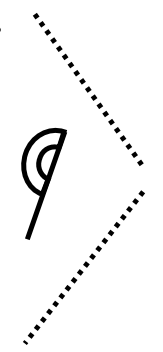

2.

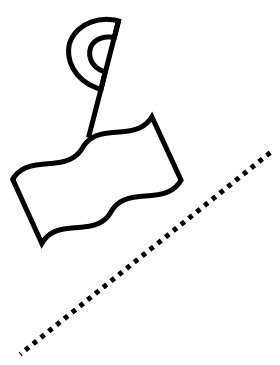

Draw, the symmetry axis in each figure, if any.

3.

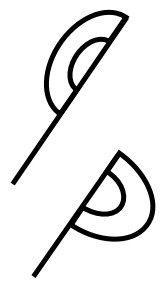

4.

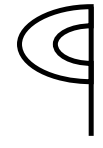

5.

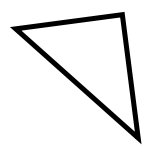

6.

Rotate the flag -90 degrees about the marked center $\mathrm{O}$ and draw the final version.

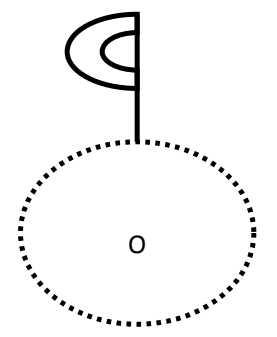

Rotate the flag 180 degrees about the marked center $\mathrm{O}$ and draw the final version.

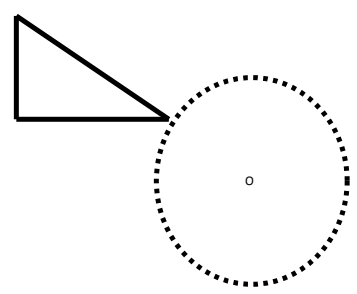

Rotate the flag 90 degrees about the marked center $\mathrm{O}$ and draw the final version.

9.

Rotate the flag 180 degrees about the marked center $\mathrm{O}$ and draw the final version.

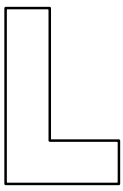


Determine the centers of rotation below, if any. Please specify if there is not a center of rotation.

10.

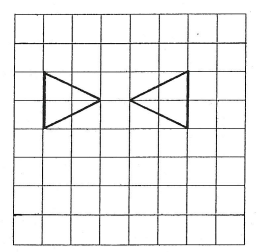

11.

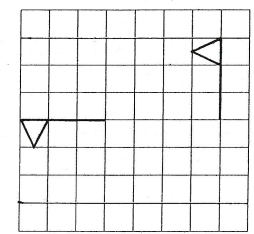

12.

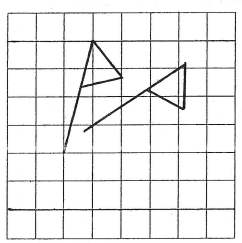

